\title{
Optical Waveguide BTX Gas Sensor Based on Yttrium-Doped Lithium Iron Phosphate Thin Film
}

\author{
Patima Nizamidin, ${ }^{1}$ Abliz Yimit, ${ }^{1}$ Ismayil Nurulla, ${ }^{1}$ and Kiminori Itoh ${ }^{2}$ \\ ${ }^{1}$ College of Chemistry and Chemical Engineering, Xinjiang University, Urumqi 830046, China \\ ${ }^{2}$ Graduate School of Environment and Information Sciences, Yokohama National University, Yokohama 240-8501, Japan
}

Correspondence should be addressed to Abliz Yimit, abliz05@yahoo.com.cn

Received 27 August 2012; Accepted 17 September 2012

Academic Editors: J. Kasperczyk and I. Milošev

Copyright ( 2012 Patima Nizamidin et al. This is an open access article distributed under the Creative Commons Attribution License, which permits unrestricted use, distribution, and reproduction in any medium, provided the original work is properly cited.

\begin{abstract}
Yttrium-doped $\mathrm{LiFePO}_{4}$ powder was synthesized using the hydrothermal method in one step and was used as a sensing material. An optical waveguide (OWG) sensor based on Yttrium-doped $\mathrm{LiFePO}_{4}$ has been developed by spin coating a thin film of $\mathrm{LiFe}_{0.99} \mathrm{Y}_{0.01} \mathrm{PO}_{4}$ onto a single-mode Tin-diffused glass optical waveguide. Light was coupled into and out of glass OWG employed by a pair of prisms. The guided wave transmits in waveguide layer and passes through the film as an evanescent wave. The sensing film is stable in air, but when exposed to target gas at room temperature, its optical properties such as transmittance (T) and refractive index $\left(n_{f}\right)$ were changed; thus, the transmitted light intensity was changed. The $\mathrm{LiFe}_{0.99} \mathrm{Y}_{0.01} \mathrm{PO}_{4}$ thin film OWG exhibits reversible response to xylene gas in the range of 0.1-1000 ppm. When the concentration of BTX gases was lower than $1 \mathrm{ppm}$, other substances caused a little interference with the detection of xylene vapor. Compared to pure $\mathrm{LiFePO}_{4}$ thin film OWG, this sensor exhibited higher sensitivity to BTXs.
\end{abstract}

\section{Introduction}

Benzene, toluene, and xylene (BTX) are volatile organic compounds (VOCs) of great social and environmental significance, are widely used in industry, and can present serious medical, environmental, and explosion dangers [1]. BTX is also classified as a human carcinogen and is a risk factor for leukemia and lymphomas. The regulated standard concentration of benzene is $1.0 \mathrm{ppb}\left(3 \mu \mathrm{g} / \mathrm{m}^{3}\right)$ in Japan. The guidelines for the upper indoor concentration limits of toluene and xylene are $70 \mathrm{ppb}\left(260 \mu \mathrm{g} / \mathrm{m}^{3}\right)$ and $200 \mathrm{ppb}\left(870 \mu \mathrm{g} / \mathrm{m}^{3}\right)$, respectively [2]. Because of BTX's acute toxicities, there has been an increasing need for highly sensitive, rapidly responding, portable devices for monitoring trace levels of them in various environmental and industrial applications.

Many works have been done on sensitivity to BTX such as electric noses [3, 4], chromatography [5], and electrochemical sensor [6], and these detectors are accurate, yet bulky and expensive, and require higher operating temperature. In comparison, the optical waveguide (OWG) sensors [7-9] are small in size, of high sensitivity, of fast response time, monitored at room temperature, and of intrinsically safe detection. Furthermore, they suffer little or no interference in the waveguide element of the sensor and can be made at a very low cost.

A simple planar OWG consists of a substrate, a thin top layer (waveguide layer) with a refractive index greater than that of the substrate and the covering material (usually air) [8]. Single-mode Tin-diffused glass waveguide has a high mechanical strength and a low loss $(-0.3 \mathrm{~dB} / \mathrm{cm})[10]$. A quite smooth surface of Tin-diffused glass waveguides suppresses the surface roughness of the middle and top layers and thereby reduces the scattering of the resulting device. Tin-diffused glass waveguides proved to be stable up to $550^{\circ} \mathrm{C}$

Lithium iron phosphate $\left(\mathrm{LiFePO}_{4}\right)$ with the olivine structure has attracted great interest as the cathode material in rechargeable lithium-ion batteries because of its high energy density, low cost, low toxicity, excellent thermal stability, and safety [11-13]. So far, lots of reports about experimental study of $\mathrm{LiFePO}_{4}$ to improve its electrochemical properties through doping other elements $[14,15]$ and 


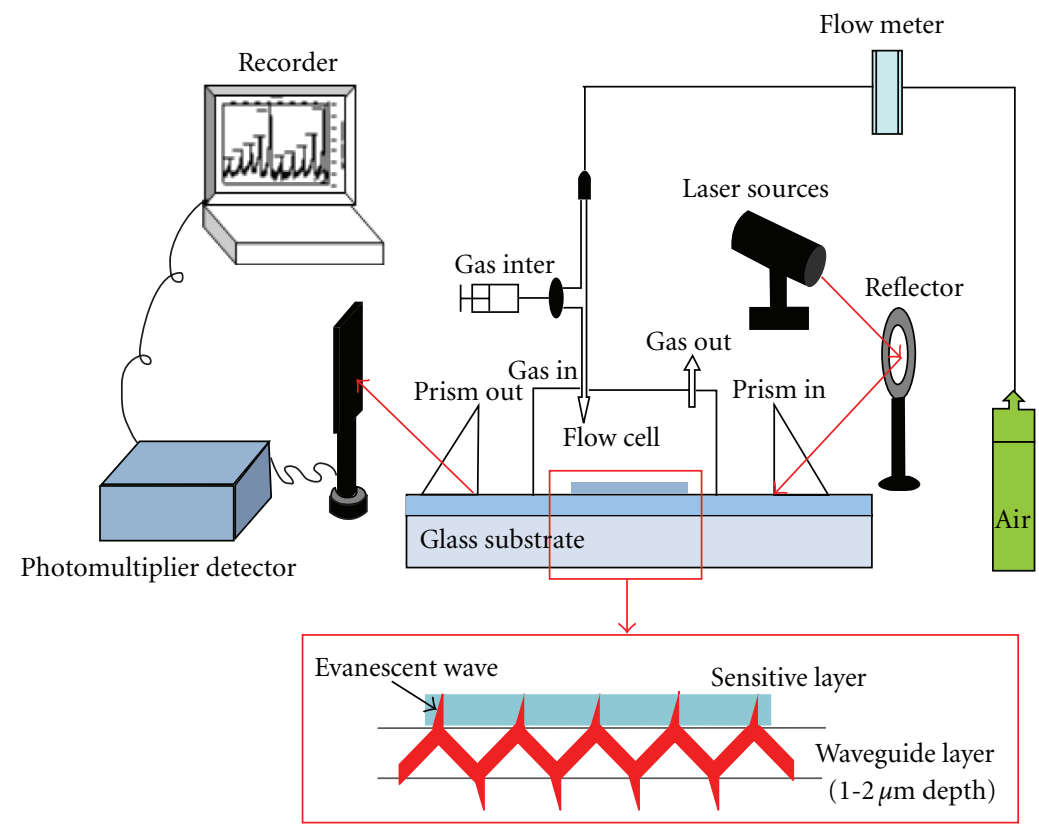

Figure 1: Schematic view of optical waveguide (OWG) sensor system.

preparing $\mathrm{LiFePO}_{4}$ thin film electrodes [16], and its sensing applications such as lithium Ion sensor, have appeared [17]. According to our survey, no gas sensor that has based on $\mathrm{LiFePO}_{4}$ and $\mathrm{LiFe}_{0.99} \mathrm{Y}_{0.01} \mathrm{PO}_{4}$ thin film has been reported.

In this paper, we describe the fabrication of the $\mathrm{LiFe}_{0.99} \mathrm{Y}_{0.01} \mathrm{PO}_{4}$ film/Tin-diffused glass optical waveguide sensor, and we use this OWG sensor system which successfully detected $0.1 \mathrm{ppm}$ (100 ppb) of xylene gas as an example of BTX.

\section{Experimental Section}

2.1. Preparation of $\mathrm{LiFe}_{0.99} \mathrm{Y}_{0.01} \mathrm{PO}_{4}$ Powder. $\mathrm{LiFe}_{0.99} \mathrm{Y}_{0.01} \mathrm{PO}_{4}$ was synthesized by hydrothermal methods [18]. $\mathrm{FeSO}_{4} \cdot 7 \mathrm{H}_{2} \mathrm{O}$ (analytically pure), $85 \mathrm{wt} \%$ of $\mathrm{H}_{3} \mathrm{PO}_{4}$ (analytically pure), and $\mathrm{LiOH} \cdot \mathrm{H}_{2} \mathrm{O}$ (analytically pure) in the molar ratio $1: 1: 3$ were mixed. Then were added ascorbic acid and $\mathrm{Y}\left(\mathrm{NO}_{3}\right)_{3} \cdot 6 \mathrm{H}_{2} \mathrm{O}\left[\mathrm{x}(\mathrm{Y}): 1-\mathrm{x}\left(\mathrm{LiFePO}_{4}\right)\right]$, respectively [15]. After that, this mixed solution was put into hydrothermal reactor (inner volume: $100 \mathrm{~cm}^{3}$ ). The hydrothermal process was performed at $150^{\circ} \mathrm{C}$ for $15 \mathrm{~h}$. The mixture was allowed to cool down to room temperature, was filtered, and the product was collected and dried under vacuum at $120^{\circ} \mathrm{C}$ for $1 \mathrm{~h}$. The powder X-ray diffraction (XRD) and the energy dispersion spectra (EDS) were used to characterize the $\mathrm{LiFe}_{0.99} \mathrm{Y}_{0.01} \mathrm{PO}_{4}$ powder.

2.2. Fabrication of $\mathrm{LiFe}_{0.99} \mathrm{Y}_{0.01} \mathrm{PO}_{4}$ Thin Film. After the enormous experimental process, the best way of fabrication of sensing film was chosen. The $\mathrm{LiFe}_{0.99} \mathrm{Y}_{0.01} \mathrm{PO}_{4}$ film was prepared by sol-gel deposition methods as described in the following way: (1) $0.05 \mathrm{~g}$ of $\mathrm{LiFe}_{0.99} \mathrm{Y}_{0.01} \mathrm{PO}_{4}$ powder was dissolved in $10 \mathrm{~cm}^{3}$ of mixed acid ( $1.3 \mathrm{wt} \%$ of phosphate acid and $5 \mathrm{wt} \%$ of ascorbic acid), and then $1 \mathrm{~cm}^{3}$ (1 wt\%) of polyvinyl alcohol (PVA) solution and a drop of surface activator (sodium dodecyl benzene sulfonate) were added. (2) $\mathrm{LiFe}_{0.99} \mathrm{Y}_{0.01} \mathrm{PO}_{4}$ solution was coated onto the surface of Tin-diffused glass OWG $(n=1.52$, with the depth of 1 $2 \mu \mathrm{m}$ of guided layer) by spin coater at $1000 \mathrm{rpm}$ for $25 \mathrm{~s}$. (3) The coated film was calcinated under vacuum at $150^{\circ} \mathrm{C}$ for $30 \mathrm{~min}$.

2.3. BTX Gases Testing. The BTX gases testing apparatus (Figure 1) was contained in compressed air sources, a flow meter, reflector, laser sources, gas mixing manifold that contained BTX gases, $\mathrm{LiFe}_{0.99} \mathrm{Y}_{0.01} \mathrm{PO}_{4}$ film/Tin-diffused glass OWG gas sensing element, photomultiplier detector, and recorder (PC). A gas mixing manifold was used to mix the air stream that contained BTX gases with a stream of pure air and to introduce the mixture into the flow cell, which enclosed the waveguide sensor. The flow cell $(2 \mathrm{~cm} \times 1 \mathrm{~cm} \times$ $1 \mathrm{~cm}$ ) was mounted on a rotational stage equipped with $\mathrm{X}-\mathrm{Y}-\mathrm{Z}$ translation. The semiconductor laser beam $(650 \mathrm{~nm})$ was introduced into the OWG using a prism coupler (glass prism, $n=1.78$; a matching liquid, diiodomethane, $n=1.74$ ), and it emerged from another prism coupler. The distance between the two prism couplers was $15 \mathrm{~mm}$. The intensity of the output light was monitored by using a photomultiplier detector, and the output light intensity was recorded by a computer. In every measurement, a new syringe was applied to inject $20 \mathrm{~cm}^{3}$ of the xylene gas sample into the flow chamber and then out from the vent (Figure 1). Pure air functioned as a carrier, and dilution gas flowed through the cell at a constant rate of $32 \mathrm{~cm}^{3} / \mathrm{min}$ in order to transfer the xylene gas to the sensor. All measurements were made at room temperature.

Standard xylene gas was obtained by vaporizing a given amount of $99.5 \%$ xylene liquid inside a $600 \mathrm{~cm}^{3}$ standard 


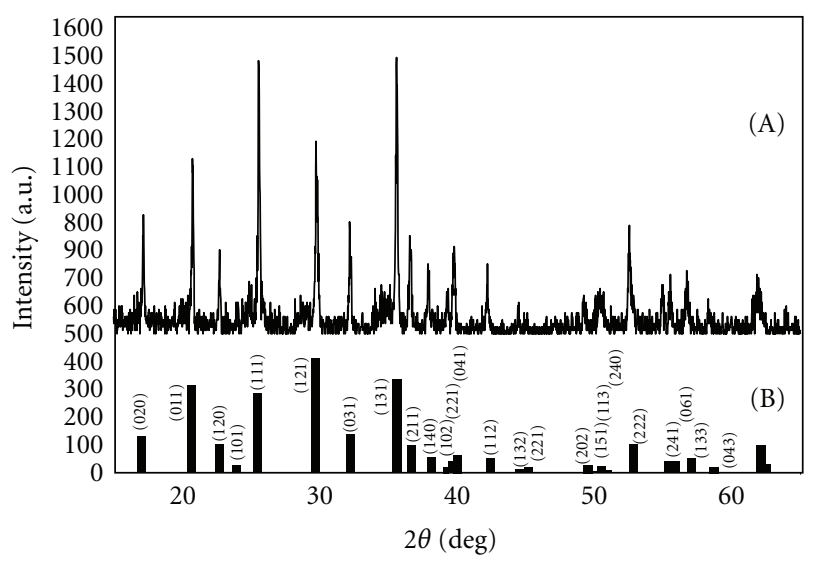

FIgURe 2: X-ray diffraction patterns of $\mathrm{LiFe}_{0.99} \mathrm{Y}_{0.01} \mathrm{PO}_{4}$ powder prepared by hydrothermal method (A) and JCPDS nos. 40-1,499 $\mathrm{LiFePO}_{4}(\mathrm{~B})$.

vessel. The concentration of the xylene gas was confirmed by a commercial xylene gas detection tube (Gastec). Different amounts of standard xylene gas were diluted to obtain the desired concentrations with pure air in a second standard vessel $\left(600 \mathrm{~cm}^{3}\right)$. Using this standard vessel dilution method, very low concentrations of xylene (in the ppm range) were obtained.

\section{Results and Discussion}

3.1. Characterization of $\mathrm{LiFe}_{0.99} \mathrm{Y}_{0.01} \mathrm{PO}_{4}$ Powder. Figure 2 shows the X-ray diffraction profiles of the Y-doped $\mathrm{LiFePO}$. $\mathrm{LiFePO}_{4}$ with an olivine structure was obtained by hydrothermal method, and the diffraction peaks of the $\mathrm{Y}$ were not observed because of the low Y content of $1 \mathrm{wt} \%$. All diffraction peaks follow its standard crystal structure patterns (JCPDS nos. 40-1,499 $\mathrm{LiFePO}_{4}$ ) [11]. Their diffraction peaks suggest that side products or impurities were not significantly present in the samples. The EDS result of Figure 3 unambiguously confirms that the particles in the Y-doped $\mathrm{LiFePO}_{4}$ included $\mathrm{Fe}, \mathrm{P}$, and $\mathrm{O}$ components with a trace of $\mathrm{Y}$.

3.2. The Sensing Layer. In OWG sensor, the sensing film's refractive index, thickness, and attenuation are major factors that affect its sensitivity. We have found that the $\mathrm{LiFe}_{0.99} \mathrm{Y}_{0.01} \mathrm{PO}_{4}$ film refractive index and thickness for the OWG BTX gas sensor were 1.899 and $104 \mathrm{~nm}$, respectively. The cutoff thickness for the $\mathrm{TE}_{0}$ mode in a thin film waveguide on glass substrate and sensitivity of thin film OWG were calculated with Runge-Kutta method [9], and the results are as shown in Figure 4. The theoretical calculation indicated that when a $\mathrm{LiFe}_{0.99} \mathrm{Y}_{0.01} \mathrm{PO}_{4}$ film of a $100-120 \mathrm{~nm}$ thickness was coated onto the surface of the Tin-diffused glass, the resulting OWG was capable of supporting a $\mathrm{TE}_{0}$ mode-guided wave, and the relative sensitivity reached its maximum limit of 12809-13988 times/cm ( $n=1.899$ ). In this experiment, the relative sensitivity of the $\mathrm{LiFe}_{0.99} \mathrm{Y}_{0.01} \mathrm{PO}_{4}$ film OWG of a $104 \mathrm{~nm}$ thickness

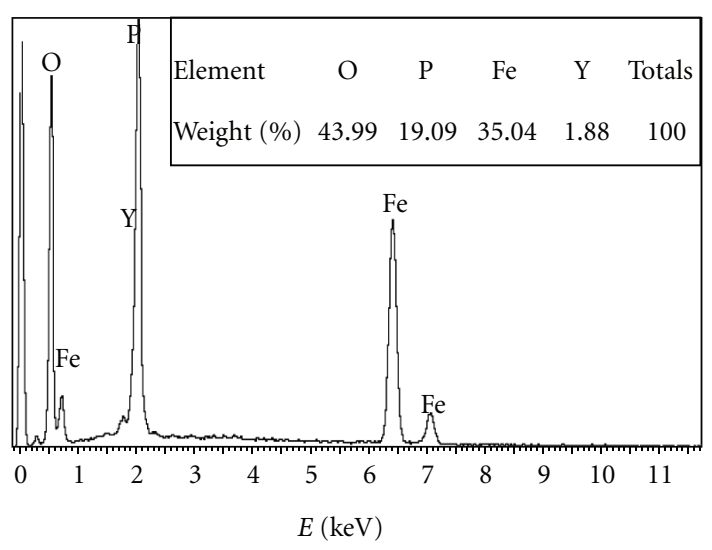

Figure 3: EDS of $\mathrm{LiFe}_{0.99} \mathrm{Y}_{0.01} \mathrm{PO}_{4}$ powder.

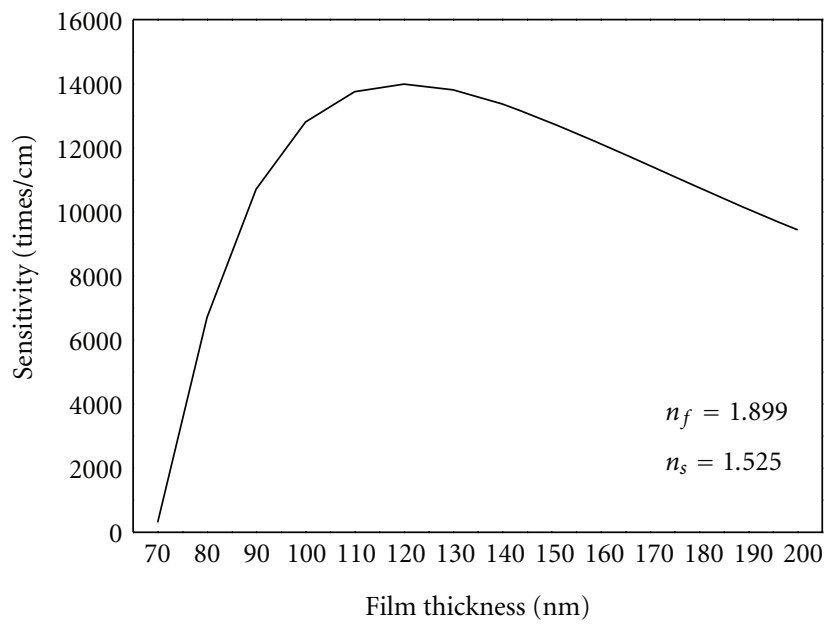

FIGURE 4: Relationship between film thickness and relative sensitivity $(n=1.899, \lambda=650 \mathrm{~nm})$.

was 13294 times/cm. The $\mathrm{LiFe}_{0.99} \mathrm{Y}_{0.01} \mathrm{PO}_{4}$ thin film attenuation was measured using cut-back method [19]; it was found that $\mathrm{LiFe}_{0.99} \mathrm{Y}_{0.01} \mathrm{PO}_{4}$ film has lower attenuation with $0.49 \mathrm{~dB} / \mathrm{mm}$. These results are providing evidence for the preparation of the $\mathrm{LiFe}_{0.99} \mathrm{Y}_{0.01} \mathrm{PO}_{4}$ film/Tin-diffused glass OWG device.

The $\mathrm{LiFe}_{0.99} \mathrm{Y}_{0.01} \mathrm{PO}_{4}$ film/Tin-diffused glass OWG was fixed in the gas testing system as shown in Figure 1 and detected various BTXs. The response of the thin film OWG sensor to various BTXs was shown in Figure 5. The testing result indicates that when the sample gas was injected into the flow chamber, there is physical adsorption between sample gas and sensing film. In the presence of benzene, toluene, chlorobenzene, or xylene, the sensor exhibited a higher response to xylene, and the response to acetone, formaldehyde, or alcohol vapor was small. This is because xylene has greater molar refractive index, and it exhibited higher absorption performance [20].

3.3. Sensing Principle. In the optical waveguide sensor, the transmitted light intensity (output light intensity) was 


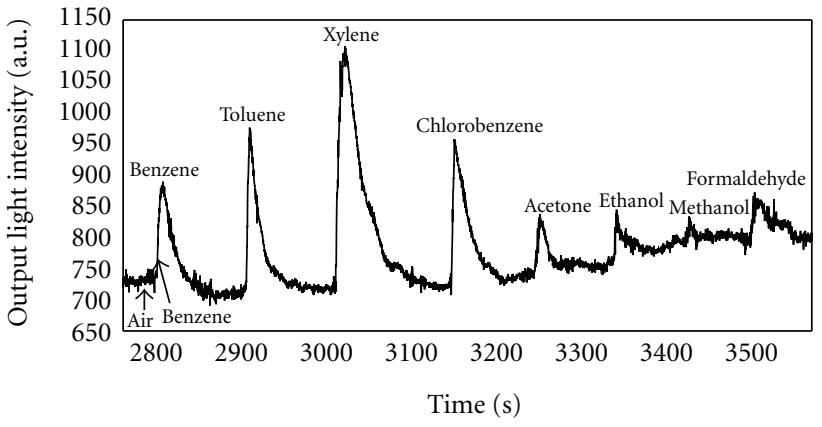

FIGURE 5: Response stereogram of OWG sensor to various gases of the same concentration (1000 ppm).

related to adsorption coefficient, refractive index, and sensing film thickness [21]

$$
I=I_{0}\left(1-a N d_{e}\right)
$$

where $I$ is the transmitted light intensity (output light), $I_{0}$ is the input light intensity, $a$ is absorption coefficient, $N$ is the reflectance number of guided wave on the surface of optical waveguide in the distance $L\left(N=L / 2 \operatorname{dtg} \theta_{\gamma}, d\right.$ is the depth of waveguide), and $d_{e}$ is the actual path length of light in the sensing film $\left(d_{e}=2 d_{f} / \cos \theta_{\gamma}, d_{f}\right.$ is the thickness of sensing film). In this case, when sensing film's absorption coefficient and refractive index were decreased, the transmitted light was increased. The $\mathrm{LiFe}_{0.99} \mathrm{Y}_{0.01} \mathrm{PO}_{4}$ film coated on the glass slide was exposed to xylene gas, and the transmittance and refractive index of this film were monitored. Transmittance was performed using an ultraviolet spectrophotometer (UV2450 Japan). When the xylene steam was not injected into the experimental environment, the $\mathrm{LiFe}_{0.99} \mathrm{Y}_{0.01} \mathrm{PO}_{4}$ film's transmittance (Figure 6) was over $99.3 \%(400-800 \mathrm{~nm})$. In the presence of xylene steam, the transmittance increased $(0.03-0.08 \%)$. The refractive index was tested by ellipsometer (Tianjin SGC-10). When the xylene steam was not injected into the experimental environment, the $\mathrm{LiFe}_{0.99} \mathrm{Y}_{0.01} \mathrm{PO}_{4}$ film's refractive index was 1.899 . While xylene steam was present, the refractive index decreased to 1.895 . Thus, an increase of output light intensity was anticipated.

3.4. Testing Results. The typical responses of the thin film OWG sensor to various concentrations of xylene gas were shown in Figure 7. As can be seen from the figure, when the xylene gas was injected into the flow chamber, the transmittance of the sensing film was increased (Figure 6), and in the meantime, the refractive index of sensing film was decreased. Thus, the testing baseline (output light intensity) steadily increased. When the xylene gas was exited, the sensor response exhibited total recovery with a return to its original baseline. The response and recovery times of the planar OWG xylene sensor were not faster than $5 \mathrm{~s}$ and $65 \mathrm{~s}$, respectively. The recovery time of the sensor was longer than its response time because of the low velocity of the dry air inflow, and thus, a longer period was required for a sufficient amount of air to reach the film in the flow chamber.

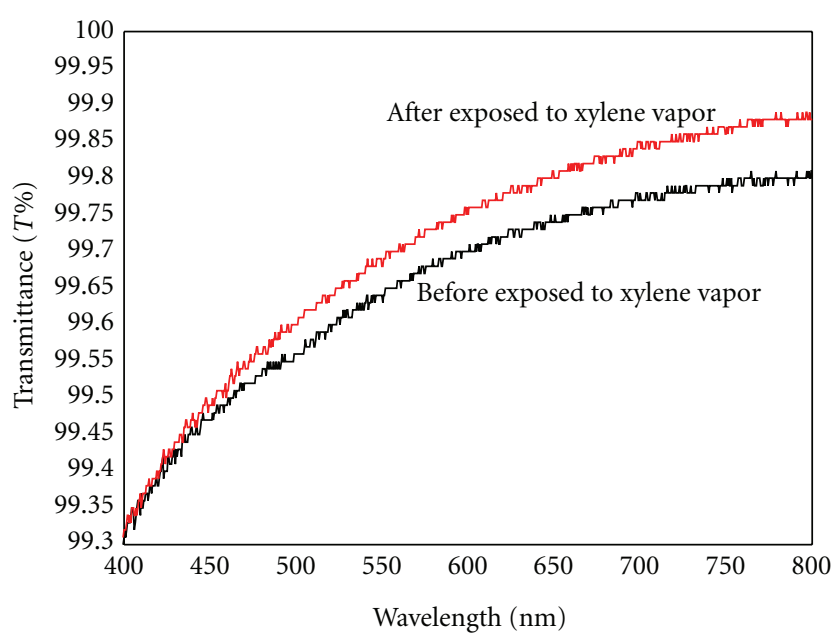

FIGURE 6: Transmittance change of the $\mathrm{LiFe}_{0.99} \mathrm{Y}_{0.01} \mathrm{PO}_{4}$ film, when it is exposed to xylene gas.

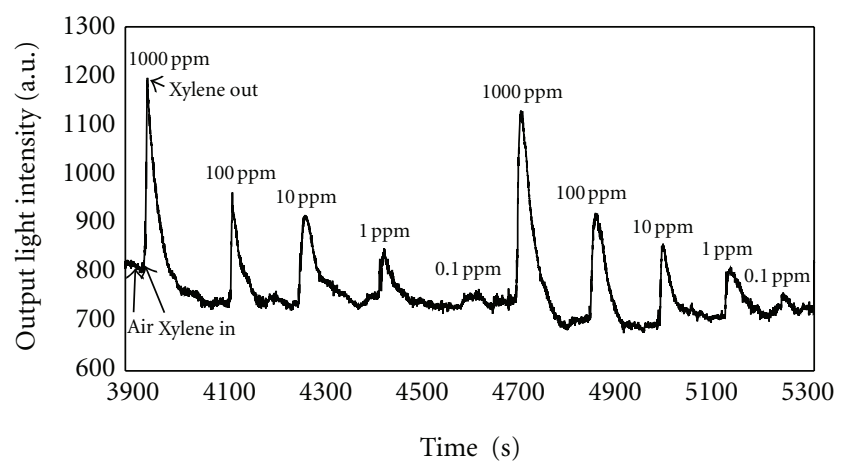

Figure 7: Typical responses of $\mathrm{LiFe}_{0.99} \mathrm{Y}_{0.01} \mathrm{PO}_{4}$ film/Tin-diffused glass OWG sensor, when it is exposed to xylene gas in air.

The increases in the signal (output light intensity), annotated as $\alpha=10 \log \left(I_{\text {xylene }} / I_{\text {air }}\right)$, were $1.8,1.16,0.9$, 0.56 , and $0.22 \mathrm{~dB}$, corresponding to $1000,100,10,1$, and 0.1 parts of xylene gas per $10^{6}(\mathrm{ppm})$ of standard atmosphere. The values of the relative standard deviation (RSD) were in the range of $\pm 1.1 \sim \pm 7.3 \%$. When the sensor was exposed to $0.1 \mathrm{ppm}$ of xylene gas, the increase in the output light intensity (signal) was 1.5 times greater than the noise level. This explained that if this OWG sensor was to be exposed to xylene vapor below $0.1 \mathrm{ppm}$, it would still demonstrate a relative response.

3.5. Selectivity. The selectivity of this OWG sensor to BTX at $1000 \mathrm{ppm}, 100 \mathrm{ppm}$, and $10 \mathrm{ppm}$ was measured (Figure 8). At $10 \mathrm{ppm}$, the sensor's response to xylene vapor was nine times greater than to acetone, ethanol, and methanol vapor, six times greater than to formaldehyde vapor, four times greater than to benzene and chlorobenzene vapors, and about two times greater than to toluene gas. The responses to ethanol, methanol, acetone, formaldehyde, benzene, and chlorobenzene are all negligible. When the concentration of BTX gas was $10 \mathrm{ppm}$, the increase in output light 


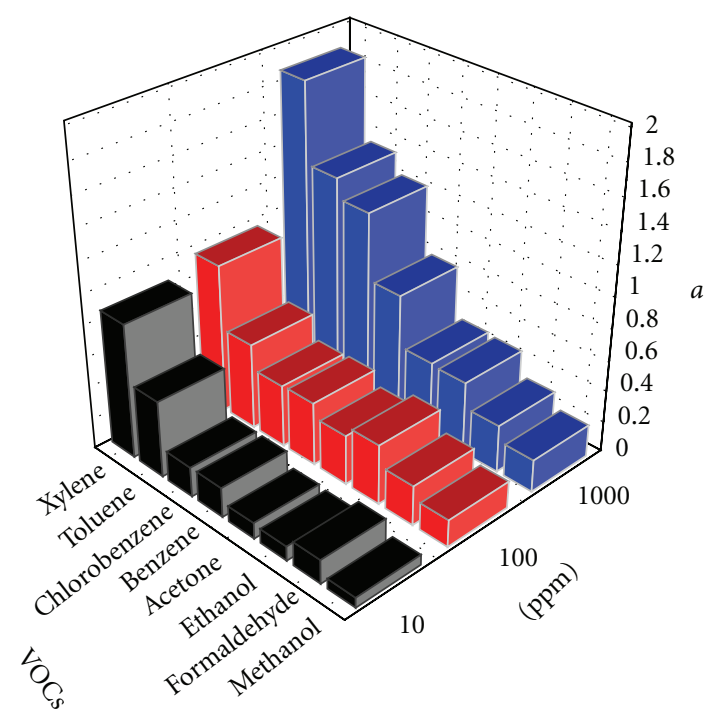

FIGURE 8: Response of OWG sensor to various organic compounds at the concentration of $1000 \mathrm{ppm}, 100 \mathrm{ppm}$, and $10 \mathrm{ppm}$, respectively.

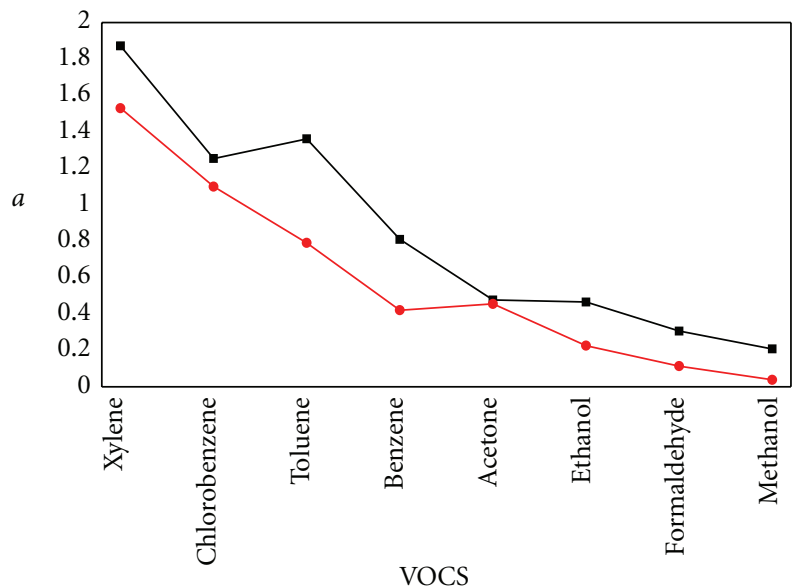

- $\mathrm{LiFe}_{0.99} \mathrm{Y}_{0.01} \mathrm{PO}_{4}$ thin film OWG

$\rightarrow \mathrm{LiFePO}_{4}$ thin film OWG

Figure 9: Selectivity of $\mathrm{LiFePO}_{4}$ and $\mathrm{LiFe}_{0.99} \mathrm{Y}_{0.01} \mathrm{PO}_{4}$ film OWG (1000 ppm).

intensity $(\alpha)$ was 0.9 for xylene, and 0.5 for toluene. While concentration of xylene gas decreased from $10 \mathrm{ppm}$ to $1 \mathrm{ppm}$, $\Delta \alpha=0.34$, and then to $0.1 \mathrm{ppm}, \Delta \alpha=0.68$. From this, we can get that the concentration of BTX was below $1 \mathrm{ppm}$, and other substances caused no interference with the detection of xylene vapor.

The experimental results presented in Figure 9 depict that, after Y doped, the $\mathrm{LiFePO}_{4}$ thin film OWG exhibited higher response to BTXs than undoped, in particular, for xylene gas has the highest response. From that, we can get that, after Y doped, the $\mathrm{LiFePO}_{4}$ thin film OWG's gas sensing properties were improved.

\section{Conclusion}

A low-cost planar OWG sensor for measuring xylene gas has been developed. The detection limits of this device were measured under the operating conditions as described above. The xylene minimum detection limit is as low as $0.1 \mathrm{ppm}$ reversibly, and with a short response time (less than $5 \mathrm{~s}$ ). This sensor can detect lower than 10 ppm of BTX with good selectivity, when the concentration of BTX gases was lower than 1 ppm; other substances caused no interference with the detection of xylene vapor. After Y doped, the $\mathrm{LiFePO}_{4} \mathrm{OWG}$ sensor exhibited higher sensitivity to BTXs.

\section{Acknowledgment}

The authors would like to acknowledge the National Natural Science Foundation of China for the support of this project under 20965008 Grants.

\section{References}

[1] S. V. Patel, T. E. Mlsna, B. Fruhberger, E. Klaassen, S. Cemalovic, and D. R. Baselt, "Chemicapacitive microsensors for volatile organic compound detection," Sensors and Actuators B, vol. 96, no. 3, pp. 541-553, 2003.

[2] Y. Ueno, T. Horiuchi, O. Niwa, H. S. Zhou, T. Yamada, and I. Honma, "Portable automatic BTX measurement system with microfluidic device using mesoporous silicate adsorbent with nano-sized pores," Sensors and Actuators B, vol. 95, no. 1-3, pp. 282-286, 2003.

[3] F. Röck, N. Barsan, and U. Weimar, "Electronic nosescurrent status and future trends," Chemical Reviews, vol. 108, no. 2, pp. 705-725, 2008.

[4] C. P. Melo, B. B. Neto, E. G. Lima, L. F. B. Lir, and J. E. G. Souza, "Use of conducting polypyrrole blends as gas sensors," Sensors and Actuators B, vol. 109, pp. 348-354, 2005.

[5] J. M. Juarez-Galan and I. Valor, "New universal, portable and cryogenic sampler for time weighted average monitoring of $\mathrm{H} 2 \mathrm{~S}, \mathrm{NH} 3$, benzene, toluene, ethylbenzene, xylenes and dimethylethylamine," Journal of Chromatography A, vol. 1216, no. 15, pp. 3003-3011, 2009.

[6] C. Sun, X. Su, F. Xiao, C. Niu, and J. Wang, "Synthesis of nearly monodisperse $\mathrm{Co}_{3} \mathrm{O}_{4}$ nanocubes via a microwaveassisted solvothermal process and their gas sensing properties," Sensors and Actuators B, vol. 157, no. 2, pp. 681-685, 2011.

[7] H. Ablat, A. Yimit, M. Mahmut, and K. Itoh, "Nation film $/ \mathrm{K}^{+}$exchanged glass optical waveguide sensor for BTX detection," Analytical Chemistry, vol. 80, no. 20, pp. 7678-7683, 2008.

[8] A. Yimit, A. G. Rossberg, T. Amemiya, and K. Itoh, "Thin film composite optical waveguides for sensor applications: a review," Talanta, vol. 65, no. 5, pp. 1102-1109, 2005.

[9] A. Yimit, K. Itoh, and M. Murabayashi, "Detection of ammonia in the ppt range based on a composite optical waveguide pH sensor," Sensors and Actuators B, vol. 88, no. 3, pp. 239245, 2003.

[10] Z. M. Qi, I. Honma, and H. Zhou, "Chemical gas sensor application of open-pore mesoporous thin films based on integrated optical polarimetric interferometry," Analytical Chemistry, vol. 78, no. 4, pp. 1034-1041, 2006.

[11] Y. D. Cho, G. T. K. Fey, and H. M. Kao, "Physical and electrochemical properties of La-doped $\mathrm{LiFePO}_{4} / \mathrm{C}$ composites as 
cathode materials for lithium-ion batteries," Journal of Solid State Electrochemistry, vol. 12, no. 7-8, pp. 815-823, 2008.

[12] C. S. Li and S. Y. Zhang, "Porous $\mathrm{LiFePO}_{4} / \mathrm{NiP}$ composite nanospheres as the cathode materials in rechargeable lithium ion batteries," Journal of Nanoparticle Research, vol. 1, pp. 242248, 2008.

[13] K. Zaghib, A. Mauger, F. Gendron, and C. M. Julien, "Relationship between local structure and electrochemical performance of $\mathrm{LiFePO}_{4}$ in Li-ion batteries," Ionics, vol. 14, no. 4, pp. 271278,2008 .

[14] C. Legrand, L. Dupont, K. Tang, H. Li, X. J. Huang, and E. Baudrin, "Structural and textural characterization of $\mathrm{LiFePO}_{4}$ thin films prepared by pulsed laser deposition on $\mathrm{Si}$ substrates," Thin Solid Films, vol. 518, no. 19, pp. 5447-5451, 2010.

[15] K. S. Park, J. T. Son, H. T. Chung et al., "Surface modification by silver coating for improving electrochemical properties of $\mathrm{LiFePO}_{4}$," Solid State Communications, vol. 129, no. 5, pp. 311314, 2004.

[16] H. Liu and J. Xie, "Synthesis and characterization of $\mathrm{LiFe}_{0.9} \mathrm{Mg}_{0.1} \mathrm{PO}_{4}$ /nano-carbon webs composite cathode," Journal of Materials Processing Technology, vol. 209, no. 1, pp. 477481, 2009.

[17] F. Sauvage, J. M. Tarascon, and E. Baudrin, "Insights into the potentiometric response behaviour vs. $\mathrm{Li}^{+}$of $\mathrm{LiFePO}_{4}$ thin films in aqueous medium," Analytica Chimica Acta, vol. 622, no. 1-2, pp. 163-168, 2008.

[18] D. G. Zhuang, X. B. Zhao, G. S. Cao, C. H. Mi, J. Tu, and J. P. Tu, "Morphology and reaction mechanism of $\mathrm{LiFePO}_{4}$ prepared by hydrothermal synthesis," Chinese Journal of Nonferrous Metals, vol. 15, no. 12, pp. 2034-2039, 2005.

[19] H. Nishihara, M. Haruna, and T. Suhara, Integrated Optics, Science Press, Beijing, China, 1st edition, 2004.

[20] S. Kondo, T. Ishikawa, and I. Abe, Adsorb Science, Chemical Industry Press, Beijing, China, 1st edition, 2006.

[21] Z. Gui Lv and L. Xue Jin, "Optical waveguide gas sensor," Chinese Journal of Instrument Technique and Sensor, vol. 5, pp. 17-19, 1990. 


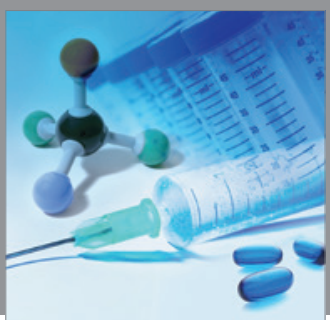

International Journal of

Medicinal Chemistry

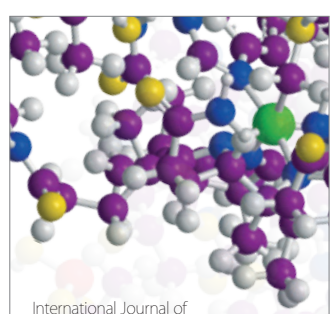

Carbohydrate Chemistry

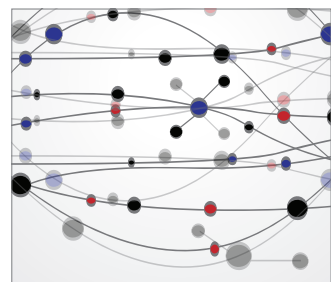

The Scientific World Journal
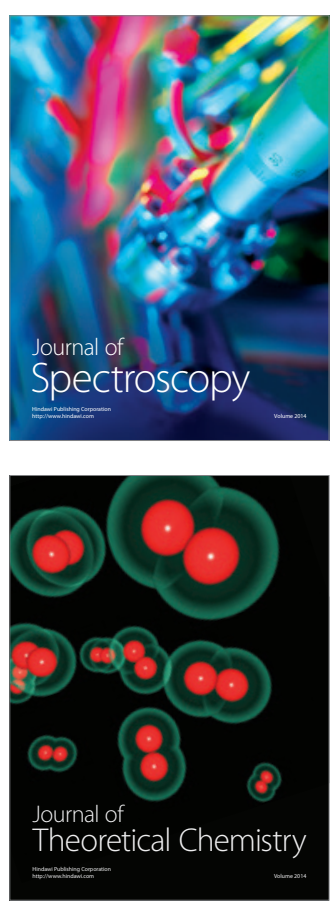
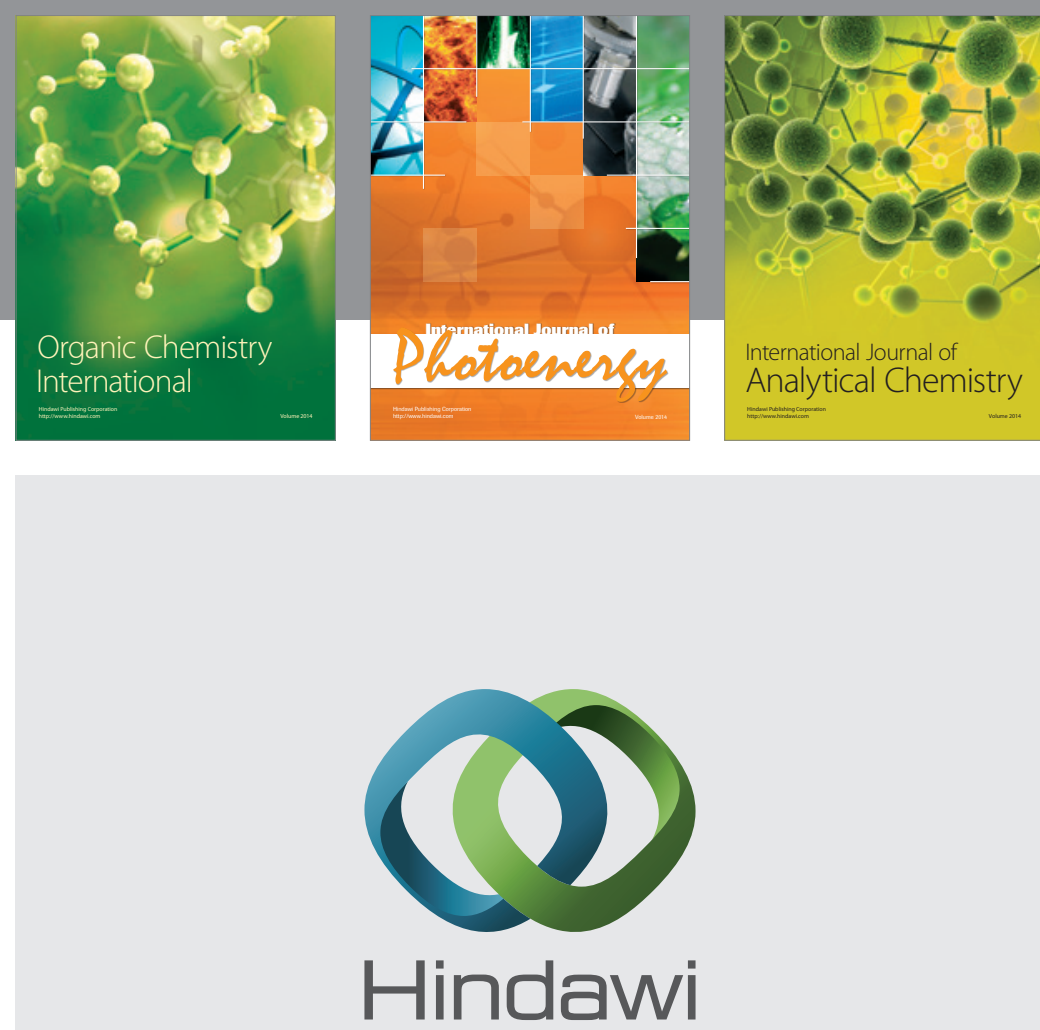

Submit your manuscripts at

http://www.hindawi.com
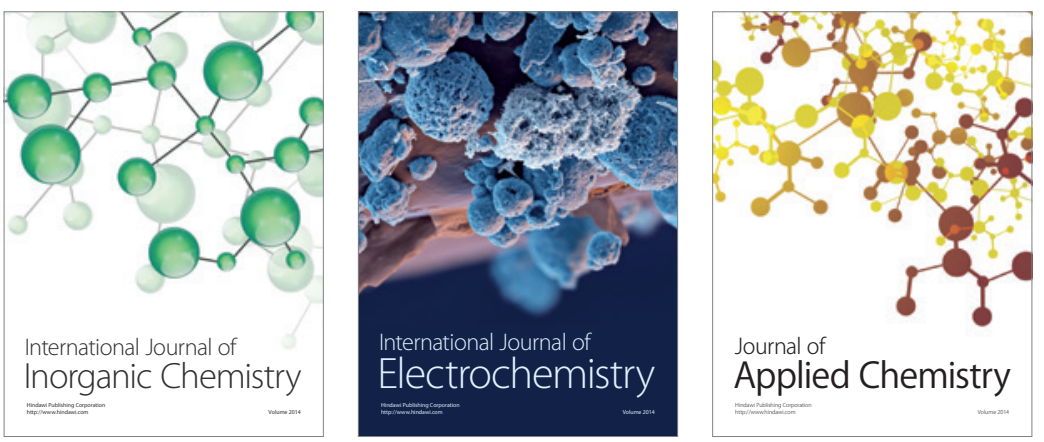

Journal of

Applied Chemistry
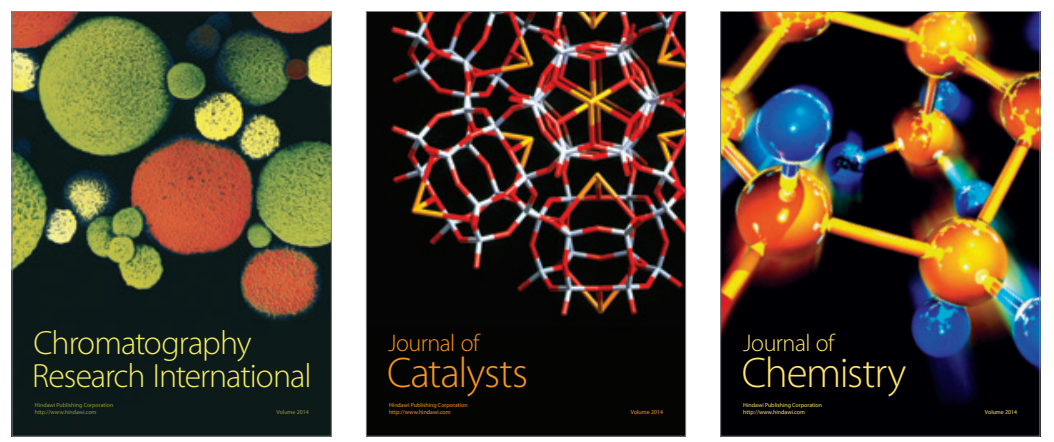
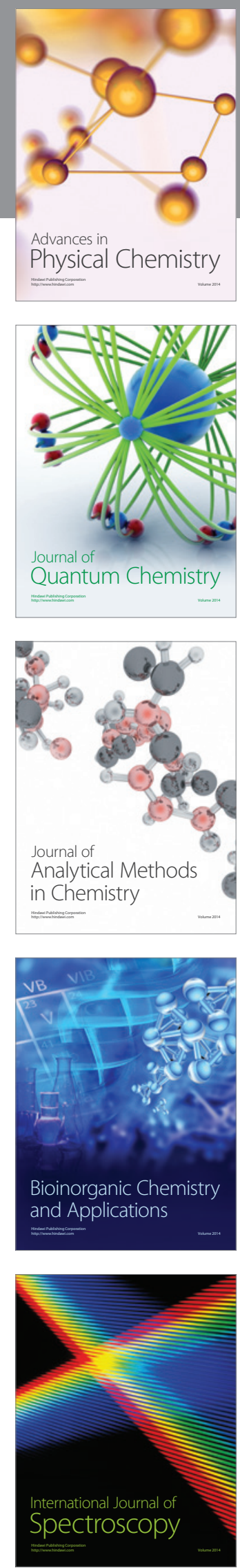